\title{
A classe feita corpo: pertencimento e discriminação social em Inferno provisório, de Luiz Ruffato
} Gabriel Estides Delgado ${ }^{1}$

\author{
Preso à minha classe e a algumas roupas, \\ vou de branco pela rua cinzenta. \\ Melancolias, mercadorias espreitam-me. \\ Devo seguir até o enjoo? \\ Posso, sem armas, revoltar-me?
}

Carlos Drummond de Andrade ${ }^{2}$

Como entidades mínimas das representações sociais, sejam primárias, vividas sob a égide do script do palco cotidiano, sejam secundárias, formalizadas pelos investimentos artísticos, os corpos tornam-se verdadeiros espaços performáticos, a lidar com os outros corpos e, sobretudo, com as contingências estruturais - históricas - de sua exploração e, progressivamente, assim há séculos se espera, com a possibilidade de sua redenção. Sobre isto, Jean-Paul Sartre traça sutil comentário em $O$ ser e o nada, ao analisar a conduta de um garçom:

Vejamos esse garçom. Tem gestos vivos e marcados, um tanto precisos demais, um pouco rápidos demais, e se inclina com presteza algo excessiva. Sua voz e seus olhos exprimem interesse talvez demasiadamente solícito pelo pedido do freguês. Afinal volta-se, tentando imitar o rigor inflexível de sabe-se lá que autômato. [...] Empenha-se em encadear seus movimentos como mecanismos regidos uns pelos outros. Sua mímica e sua voz parecem mecanismos, e ele assume a presteza e rapidez inexorável das coisas. Brinca e se diverte. Mas brinca de quê? Não é preciso muito para descobrir: brinca de ser garçom. A criança brinca com seu corpo para explorá-lo e inventariá-lo, o garçom brinca com sua condição para realizá-la (Sartre, 1997 [1943], p. 105-106).

A transcrição teatral de uma representação cotidiana guarda sentidos estruturais no que tange ao pertencimento social dos sujeitos. É que, como afirma Erving Goffman:

\footnotetext{
${ }^{1}$ Doutorando em literatura na Universidade de Brasília (UnB), Brasília, DF, Brasil. E-mail: gabrielestides@gmail.com

${ }^{2}$ Devo a Andrea Saad Hossne a lembrança desses versos.
} 
A sociedade está organizada tendo por base o princípio de que qualquer indivíduo que possua certas características sociais tem o direito moral de esperar que os outros o valorizem e o tratem de maneira adequada. Ligado a este princípio há um segundo, ou seja, de que um indivíduo que implícita ou explicitamente dê a entender que possui certas características sociais deve de fato ser o que pretende que é. Consequentemente, quando um indivíduo projeta uma definição da situação e com isso pretende [...] ser uma pessoa de determinado tipo, automaticamente exerce uma exigência moral sobre os outros, obrigando-os a valorizá-lo e a tratá-lo de acordo com o que as pessoas de seu tipo têm o direito de esperar. Implicitamente também renuncia a toda pretensão de ser o que não aparenta ser e, portanto, abre mão do tratamento que seria adequado a tais pessoas. Os outros descobrem, então, que o indivíduo os informou a respeito do que é e do que eles devem entender por "é" (Goffman, 2009 [1959], p. 21-22).

$\mathrm{O}$ registro das impressões que caracterizam um garçom como garçom deve, portanto, figurar como exemplo genérico da roldana social. À determinada posição vincula-se a herança histórica de seus atributos, o que é suficiente para explicar o roteiro de subalternidade em sistemas desiguais. Assim, volta-se ao comentário de Sartre, que estende o repertório de funções e obrigações:

Existe a dança do dono da mercearia, do alfaiate, do leiloeiro, pela qual se empenham em persuadir seus clientes de que não passam de dono de mercearia, leiloeiro, alfaiate. Um vendedor que se alheia em sonhos é ofensivo para os compradores, pois já não é completamente vendedor. A cortesia [ou sociedade] exige que se circunscreva à função, assim como o soldado em posição de sentido faz-se coisa-soldado com um olhar direto, mas que nada vê, e não foi feito para ver, porque é o regulamento, e não o interesse do momento, que decide o ponto que deve fixar (o olhar "fixo a dez passos de distância"). Vemos quantas precauções são necessárias para aprisionar o homem no que é, como se vivêssemos no eterno temor de que escape, extravase e eluda sua condição (Sartre, 1997 [1943], p. 106).

O corpo realmente pode ser uma prisão, quando parte de suas características é essencializada. O exemplo maior, aqui, é a exploração e opressão que ainda vitimam a população negra e mestiça no Brasil. Tomam-se, como bem se sabe e se vive, o caráter, a potencialidade, a 
inteligência e as demais contingências e constructos identitários e sociais pela cor da pele. Na sociedade brasileira do século XX e começo do século XXI os corpos aparecem como pontos centrais de observação da desigualdade social e de sua manutenção. Antes de, como escreve Goffman, pretender ser, já se nasce sendo, posto que a carga informativa do que se "é" em relação aos outros é potencialmente involuntária.

Espaços plurais, por onde a expressividade humana ganha concretude, os corpos plasmam em si desejos, intenções e embates. Sua linguagem, por vezes ostensiva, igualmente pode ser invisível a quem a expressa. Normalmente atrelada ao habitus do grupo social no qual é estruturada e, ao mesmo tempo, do qual é estruturante, sedimenta-se quase sempre como a objetivação das condições materiais e históricas herdadas ${ }^{3}$. Sem que tais propriedades sejam desencobertas, revelados os papéis que cumprem socialmente, prevalece o apagamento de sua gênese.

A invisibilidade da gênese dos usos do corpo - gênese histórica e material, como afirmado anteriormente - parece conduzir o trabalho mimético de Luiz Ruffato em Inferno provisório. Atento aos corpos estigmatizados, prisioneiros de si mesmos, da cor de suas peles, das vestimentas puídas ou das condutas operárias ("broncas", "rústicas" etc.), Ruffato constrói sua obra no sentido de desmascarar a lógica econômica e violenta que a uns caleja e a outros, às custas dos primeiros, fornece o gozo travestido de mérito, esquecida a exploração. A manutenção do status quo depende não só do capital econômico, de vulgar autorreprodução, mas também do domínio das esferas simbólicas do poder, saturadas no corpo. Para Bourdieu:

Tratando-se de pensar o mundo social, nunca se corre o risco de exagerar a dificuldade ou as ameaças. A força do pré-construído está em que, achando-se inscrito ao mesmo tempo nas coisas e nos cérebros, ele se apresenta com as aparências da evidência, que passa despercebida porque é perfeitamente natural (Bourdieu, 1989, p. 49).

O não reconhecimento, ou desconhecimento, do substrato simbólico das trocas sociais naturaliza a divisão econômica das classes como matéria inalterável, em que os membros de cada classe aceitam os

\footnotetext{
3 “Tudo se passa como se os condicionamentos sociais vinculados a uma condição social tendessem a inscrever a relação com o mundo social em uma relação duradoura e generalizada com o próprio corpo, uma maneira de posicionar o corpo, de apresentá-lo aos outros, de movimentá-lo, de reservar-lhe um lugar, que lhe dá sua fisionomia social” (Bourdieu, 2007 [1979], p. 439).
} 
próprios lugares e usos como imanentemente seus, isto é, há a naturalização de diferenças reais (Bourdieu, 2007 [1979], p. 66). O tom fatalista de Inferno provisório parece apontar para tal ideologia subjacente às relações e que vem marcada no corpo.

As maneiras de se vestir, bem como as noções de gosto, por exemplo, acabam por reproduzir as flagrantes oposições entre as diversas frações de classe. O portar-se bem, a elegância, o exato tom de voz, enfim, os usos do corpo que franqueiam o acesso a estratos sociais superiores parecem, pois, como entende Bourdieu, sempre escapar das mãos daqueles que buscam fugir à sua condição primeira. Não basta ao sujeito a incorporação de padrões de beleza, comportamento e postura atribuídos às classes dominantes como fatores naturais, intrínsecos a estas, posto que:

A dinâmica da distinção social não se esgota no conflito simbólico pela imposição de uma dada representação da sociedade, mas prolonga-se na produção incessante de novos gostos socialmente diferenciadores e no abandono progressivo das práticas culturais entretanto apropriadas pelas camadas subalternas (Bethencourt e Curto, 1989, p. 4).

\section{O livro das impossibilidades}

Composto por três narrativas, o volume IV de Inferno provisório, $O$ livro das impossibilidades (Ruffato, 2008), acena a todo instante para as maneiras de ver do senso comum e, assim como nos outros livros que compõem o painel romanesco de Ruffato, utiliza mecanismos originais, criativos, para operar a transfiguração mimética da dinâmica referencial. Em vez da identificação comum pelos nomes das personagens, Ruffato, ao escrever, sobrepõe ao nome, à identidade tratada, os objetos que circundam a cena. Caso optasse pela descrição tradicional das personagens, expondo aos poucos seu jeito, sua vestimenta, entremeados por qualquer outro fator psicológico, pensamento ou desejo, não alcançaria seu efeito literário próprio. Ao contrário, opta por duas variantes, que operam juntas: 1) ao embrenharse na consciência íntima das personagens, por meio de seu narrador aderente, expõe diretamente sua maneira de ver, sempre saturada de preconceitos sociais. Mas também 2) descola quase sempre seu narrador da consciência que busca mimetizar; neste ponto, é possível distinguir a 
autonomia do narrador frente ao mundo narrado. Tal autonomia é patente na prática descritiva que privilegia os objetos na caracterização das personagens ou, ainda de maneira mais flagrante, apresenta sensações e sentimentos através do que seria sua vinculação material, de classe, sujeitos ao poder de consumo. Em outras palavras: dá-se a ver o fundamento material da subjetividade.

Em "Era uma vez", conta-se a história de uma viagem de férias de Luís Augusto, de Cataguases (MG), cidade onde morou na adolescência, para São Paulo, na década de 1970. Como em outras narrativas de Inferno provisório, permanece o trauma de adaptação à cidade gigantesca que se descortina. Hospedado na casa de sua madrinha, Alzira, Luís Augusto (Guto) acaba por enturmar-se com Nílson, neto, também adolescente, de Alzira.

A apresentação de Guto à turma de amigos de Nílson figura como ritual de iniciação a um ambiente outrora desconhecido. E, como se verá, as marcações de desencaixe entre o provincialismo de Guto e o cosmopolitismo de megalópole, ainda que de classe média baixa, do restante do grupo dar-se-á através da explicitação da violência simbólica impingida ao estrangeiro, que, fora as razões dos vínculos familiares, nunca acessaria tal espaço.

Caminharam sem pressa duas quadras, quebraram à esquerda e estacaram diante de uma casa abandonada na Rua Sérgio Cardoso, os dedos da mão do Guto magoados de frio. Nílson, coturno, longo capote preto, chapéu-de-feltro mesma cor, assobiou um trinado, esperou. Logo, semelhante ritmo, soou a resposta. Limpeza, sussurrou e, após examinar um e outro lado da calçada, pularam o muro enveredando-se por entre o mato alto que engolia a varanda. Avançaram rente à parede, alcançando um porão escuro de onde provinham vozes excitadas. Ao vislumbrar ensombrada à porta a figura franzina do Guto, abraçado à descosida blusa verde, equilibrando-se, calça de tergal cor indefinida, sobre o quichute esmolambento, alvoroçaram-se Edu - cabelo black-power, casaco-militar, às costas costurado enorme coração vermelho, bute, calça-lee alisada com tijolo Zezão - gordo, pretas japona, camiseta, calça de veludo, Bamba Maioral, comprida corrente de onde pendia um crucifixo mirrado, imberbe, calhambeques ilustram a vermelha gravata, terno náicron cinza-chumbo, pulôver creme, sapato Vulcabrás 752, Jimmy berrou: 
- Quem é esse cara, Nílson?

$[\ldots]$

- Caralho, Nílson, ele está de quichute!, expôs o Jimmy.

- E calça-de-escritório, alegrou-se o Zezão.

- Ele é do interior, explicou o Nílson (Ruffato, 2008, p. 40-41, grifo no original).

A frugalidade da cena, aparentemente inofensiva, vai marcar a vida de Luís Gustavo. Décadas mais tarde, tendo imigrado para São Paulo, Guto reconhece o primo. Há no caso uma inversão de posições, e o então garoto desprezado por suas vestes, tornado jornalista ou em vias de se formar, paira superior na observação que lhe é atribuída: "No crachá o sobrenome qualquer dúvida dissipava: detrás do mexicano bigode que ornava o rosto de pouco sol, habitava o mesmo Nílson de quinze anos menos [...] expunha-se agora terno-gravata de segurança da Mappin, radiocomunicador na mão esquerda, radares os olhos pretos" (Ruffato, 2008, p. 15). Aqui, como no trecho anterior, não deixam de prevalecer as aparências. A maneira direta de descrever o corpo da personagem deve causar estranheza ao leitor, posto que nos dois trechos não há adensamento psicológico, ao contrário. Fica-se com a bruta definição do olhar passageiro, com o protagonismo de objetos e maneiras, reveladores da condição social da personagem retratada. A conversão do olhar proposta por Ruffato é antepor as experiências de classe, seja no caso de Guto, seja no caso de Nílson, seja na década de 1970, seja na de 1990, a qualquer mergulho "psicologizante". O efeito de leitura propõe a descoberta dos dramas dessas personagens passando inevitavelmente pelo crivo do olhar social que reifica seus corpos.

Põe-se a nu o olhar social, classista e distintivo. Este olhar normalmente agrupa-se, conforme entendido por Pierre Bourdieu, ao redor de diferentes habitus, ou práticas sociais, que, por sua vez, carregam em si, como linguagem corporal, sua proveniência e pertencimento de classe. A humilhação sofrida por Guto é, inicialmente, para o senso comum, da ordem estrita do gosto. No entanto, como observada por Ruffato, a ordem estrita do gosto revela-se como sociologia do gosto, indicador padrão de diferenciações sociais. "Assim, o gosto é o operador prático da transmutação das coisas em sinais distintos e distintivos, das distribuições contínuas em oposições descontínuas; ele faz com que as diferenças inscritas na ordem física dos 
corpos tenham acesso à ordem simbólica das distinções significantes" (Bourdieu, 2007 [1979], p. 166).

Formalmente comprometido com o desmascaramento do olhar de sobrevoo, que pouco acrescenta em sua ânsia por distinções e filiações capazes de rapidamente apartar, segregar e confinar, Ruffato também se arma tecnicamente para percorrer as ruínas de suas personagens pobres, subempregadas, viciadas, negligenciadas e, por fim, esquecidas, inclusive, pela maior parte da produção romanesca contemporânea brasileira (Dalcastagnè, 2005). Um de seus experimentos, exitoso pelo resultado alcançado, é o que Giovanni Ricciardi $(2007$, p. 50) chamou de "estética da enumeração". Já Karl Erik Schøllhammer (2007, p. 73) identifica nessas estruturas narrativas que se reduzem a longas listas de substantivos emblemas de reconhecimento da complexa matéria referencial. Veja-se um exemplo. Na narrativa "Zezé \& Dinim (sombras do triunfo de ontem)", também de O livro das impossibilidades (Ruffato, 2008), o leitor defronta-se com Matias, bêbado, no dia do nascimento de seu filho, Zezé. Mais do que a personagem propriamente dita, tem-se a concretude do ambiente que a envolve. É a partir deste que Matias ganha suas feições, inescapável a realidade.

tarde anterior engolia umas-e-outras no botequim do Zé Pinto [...], dona Zulmira adentrou encabulada, vista revelando a cerâmica vermelha manchada de poças, bramas e pingas, escarros e pegadas de mijo, salpicada de bitucas e paus-de-fósforo, assoprada de cinzas e pó-de-giz e na morna sombra sufocada de fumaça, ciciou, Matias, ô Matias, desce lá que a Nazaré está passando mal... (Ruffato, 2008, p. 92, grifo no original).

Mais à frente, propõe aos amigos expedição à área de prostituição da cidade ("Ilha"), sem atentar para o trabalho de parto da esposa Nazaré.

E aí?, o povinho não se anima não?, e [...] encerraram a questão e, doidos por um bloco-do-sujo, baixaram na Ilha, de onde, pós vermutes, fernetes, são-rafaéis, coquinhos, camparis, martínisdoce, underbergues, catuaba-jurubebas, maravilhas-de-são-roque, rabos-de-galo e uísques nacionais, ovos coloridos e de-codorna, salames e queijos-prato, jilós cozidos e pés-de-galinha, azeitonas e coxinhas, emergiram na Avenida Astolfo Dutra, paralelepípedos e reco-recos (Ruffato, 2008, p. 93, grifo no original).

A lista enorme de aperitivos, surrealista na quantidade, "sem a estrutura verbal e adverbial que marcaria sua posição na paisagem da 
ação", juntamente à cena anterior - suja - de botequim mambembe, é o resultado de uma operação que empobrece sintaticamente o texto para enriquecê-lo semanticamente (Schøllhammer, 2007, p. 73). Chega-se à realidade sensorial, de requinte concreto, isto é, não há saídas de leitura para além dos cheiros, objetos e sujeira invocados. Apostar nesse tipo de condução formal não necessariamente leva ao documentarismo, como facilmente pode-se ver nos trechos anteriores. A transfiguração artística está presente na amplificação, sem subterfúgios, da ruína.

Novamente, condições externas, como o "terno-gravata de segurança da Mappin", descrito em "Era uma vez", objetificam os sujeitos. Seguindo a arapuca estrutural que sorve as personagens, tais "coágulos insolúveis de realidade" (Schøllhammer, 2007, p. 72) são índices de classificação; em outras palavras, artifícios figurativos que, no seu excesso e condição majoritária sobre as demais caracterizações, confirmam o engajamento materialista do autor. É assim que por uma estante de livros, descrita em "Carta a uma jovem senhora", o leitor, colado à perspectiva autoral, intelectualizada, vê-se próximo de Laura. O que os livros revelariam a respeito dessa personagem?

$\mathrm{Na}$ sala, uma estante, trinta e poucos livros, José Mauro de Vasconcelos e Jorge Amado, Harold Robbins e Sidney Sheldon, J.G de Araújo Jorge e Lobsang Rampa, Carlos Drummond de Andrade e Graciliano Ramos, Neimar de Barros e Padre Zezinho. "Você já leu isso tudo?", perguntou, espantado, "Claro, né, eles não estão aí só de enfeite...". Ela estava se preparando para ser alguém na vida. "Laurinha vai estudar advocacia, não vai ficar aqui comendo algodão que nem todo mundo não. Quero ela longe da fábrica!"' (Ruffato, 2008, p. 77).

Mesmo que já saibamos tratar-se de moradora de bairro de classe média baixa, "aglomeração de residências rigorosamente iguais" (Ruffato, 2008, p. 77), o caráter heterogêneo e escolar da parca estante de livros parece não deixar dúvidas sobre as possibilidades muito limitadas de ascensão social, ainda que pelo estudo formal. É que nesse caso, como nos outros, não basta apenas a intenção e o esforço, mesmo que muito distantes da sujeira e degradação relatadas em "Zezé \& Dinim". É preciso atentar-se para "a imagem social da posição considerada e do futuro que se encontra aí objetivamente inscrito" (Bourdieu, 2007 [1979], p. 29). Em O livro das impossibilidades (Ruffato, 2008) e em Domingos sem Deus (Ruffato, 2011), assim como em todo 
Inferno provisório, lê-se a média das disposições das classes sociais e não a redenção do caso único, da excepcionalidade às vezes tão exaltada que chega a ganhar ares de regra.

\section{Domingos sem Deus}

As travas à mudança social, sobretudo economicamente sistêmica, devem ter, pois, eficácia simbólica. Esta vai concretizar-se pelo que Michel de Certeau (1996 [1990], p. 239) chama, em A invenção do cotidiano, de maquinaria da representação, que manteria os corpos submetidos a uma norma:

Deste ponto de vista, até as roupas podem passar por instrumentos, graças aos quais uma lei social se assegura dos corpos e de seus membros, regula-os e os exerce por mudanças de moda como em manobras militares. O automóvel, como um espartilho, também os molda e os conforma a um modelo postural. É um instrumento ortopédico e ortopráxico. Os alimentos selecionados por tradições [e, necessário lembrar, imperativos econômicos] e vendidos nos mercados de uma sociedade modelam igualmente os corpos mediante a nutrição; impõem-lhes uma forma e um tônus que têm valor de uma carteira de identidade. Os óculos, o cigarro, os sapatos etc. refazem, à sua maneira, o "retrato físico" [...] (Certeau, 1996 [1990], p. 240).

Levado por essas considerações, o intelectual francês chega a duas questões fundamentais que reafirmam a ordem do sistema capitalista dividido em classes, mas igualmente sugerem uma resposta desordenadora, que, ainda dentro da simbologia corporal4, deve ser rapidamente reprimida.

Onde se acha o limite da maquinaria pela qual a sociedade se representa por gente viva e dela faz as suas representações? [...] Pois onde é que há e quando, algo do corpo que não seja escrito, refeito, cultivado, identificado pelos instrumentos de uma simbólica social? Talvez, na fronteira extrema dessas escrituras incansáveis, ou furando-as com lapsos, exista somente o grito: ele escapa, escapa-lhes. Do primeiro grito até o último, alguma coisa de outro irrompe com ele, que seria sua diferença em face do

\footnotetext{
${ }^{4}$ Ora, o corpo segue sendo a "única manifestação sensível da 'pessoa”” (Bourdieu, 2007 [1979], p. 183).
} 
corpo, uma diferença ora in-fans e mal-educada, intolerável na criança, a pessoa possessa, o louco ou o doente - uma falta de "compostura" (Certeau, 1996 [1990], p. 240).

Luiz Ruffato nos diz dessa experiência assustadora de ordenamento corporal, em que prevalece a conservação e não a figura do grito, em uma das seis narrativas de Domingos sem Deus. "Sorte teve a Sandra", breve história de uma migrante, conduz alta voltagem dessas cargas, por vezes invisíveis, de poder e cerceamento. Ainda menor de idade, Sandra é levada como doméstica para o Rio de Janeiro para trabalhar na casa onde moravam os filhos do doutor Prata, patriarca da família politicamente mais poderosa do universo ficcional ruffatiano ${ }^{5}$. O destino migrante, por sorte, combinava com suas intenções: "Embora atirada às faldas de Cataguases, no engatinho da adolescência, arremedava-se carioca, caprichante no sotaque melodioso e sibilante e nos gestos despachados de 'gente de cidade grande'" (Ruffato, 2011, p. 45).

Como escreve Marcos Vinícius Ferreira de Oliveira (2013, p. 190) a respeito de outra narrativa da série, extensível ao drama de Sandra, o empenho maior é pela consecução das aparências, "porque são elas que garantem os lugares de proeminência e abrem os caminhos para os trânsitos com menor número de percalços", independentemente de os esforços mostrarem-se quase sempre estéreis, presos que ficam à reprodução como se automática das classes. É porque as tentativas de agregação dos sujeitos "ao grupo dos detentores legítimos, ou seja, hereditários, da maneira adequada sem serem o produto das mesmas condições sociais" faz com que estes encontrem-se confinados,

[...] Façam o que fizerem, na alternativa da hiperidentificação ansiosa ou do negativismo que, na própria revolta, confessa sua derrota: ou a conformidade de uma conduta "tomada de empréstimo", cuja correção ou até mesmo hipercorreção lembra que ela imita e que macaqueia, ou a afirmação ostensiva da diferença que é votada a aparecer como uma confissão da impotência a identificar-se (Bourdieu, 2007 [1979], p. 91).

\footnotetext{
${ }^{5}$ Em Domingos sem Deus, o patriarca da família Prata é prefeito de Cataguases. Neste, como nos outros livros da série Inferno provisório, as personagens principais, ainda que migrantes, têm suas origens na pequena cidade da Zona da Mata de Minas Gerais, a qual, também berço do escritor, serve de modelo para o trabalho ficcional de Ruffato.
} 
No caso de Sandra, não há revolta, e a tentativa é pela dissolução das diferenças entre ela, seu corpo, e a família Prata, identificada em um primeiro momento por Dona Diana, que trazia consigo "cheiro bom de povo rico", além de ser "educadíssima por detrás dos óculos-escuros" (Ruffato, 2011, p. 46). As maneiras "adequadas" por vezes perseguidas pelos grupos subalternos, como se vê, transcendem o universo do consumo e não podem ser garantidas nem por aqueles que fazem fortuna; pertencem ao terreno das filiações hereditárias, de origem, capazes de exercer domínio (fascínio ou ódio) simbólico sobre os demais sujeitos.

Após engravidar no Rio de Janeiro, Sandra é demitida pelos Prata, regressa a Cataguases, onde delega o cuidado do rebento à família para novamente morar na capital fluminense. Lá, deixa-se levar por um "sujeito zona sul", empregando-se em uma "boate chique de Ipanema" (Ruffato, 2011, p. 49). Veja-se que, ao contrário da concretude rítmica e palpável da já comentada estética da enumeração, passa-se, ainda no terreno simbólico, a classificações sociais difusas, filtradas pela subjetividade ingênua da protagonista, que, em espaço desconhecido, vive falso sentido de pertencimento de classe (ou ascensão). Como profissional do sexo, consegue alugar "um quarto-e-sala na Rua São Clemente, em Botafogo, o Cristo Redentor de esguelha, para deslembrar os antigos tempos de senzala". Estabelecida, encanta-se pelos "olhos furta-cor", diga-se claros ${ }^{6}$, de um suposto músico:

Carregou-o para o apartamentinho, presenteou-o com um cordãozão de ouro - que ele, envergonhado, se recusava a usar -, um violão Ovation, importado, um aparelho de som, discos, óculos-escuros, calças-lee, tênis All Star, enfim, mal acostumou-o, apenas para ronronar, manhosa, em seus ouvidos (Ruffato, 2011, p. 49).

Já o superlativo cordão de ouro denuncia o desajuste de gosto que, pode-se inferir, o amante não aceita usar por ser alheio a suas disposições sociais, canalizadas em grande parte, reafirma-se, para o vestuário. Logo o abismo entre Sandra e o amante vai-se abrindo, e ele "mais e mais exigente, impositivo, desdenhoso de seu jeito de falar, vestir, portar-se, Cruz-credo, Sandra!, vê se toma jeito!" (Ruffato, 2011,

\footnotetext{
${ }^{6}$ Constata-se a diferença hierárquica, mantida até hoje, entre aqueles de olhos claros e a "senzala" moderna, exemplificada pela "minúscula dependência-de-empregada, escura e embolorada, cama e guarda-roupa imprensados" (Ruffato, 2011, p. 46) do apartamento dos Prata no Rio de Janeiro.
} 
p. 50, grifo no original), alheia-se gradativamente até abandoná-la grávida, roubando tudo o que havia no apartamento.

Inadvertidamente, prevalecem as aparências dentro do mesmo grupo social, seja por meio de produtos de consumo, seja por histórias, posturas ou entonações tornadas públicas, que se de imediato identificadas como frágil embuste pelas classes privilegiadas, no bairro operário de Sandra em Cataguases passariam como exemplo.

Depois, quando soube-se com aids - ela e o Kaíke, ainda mamão , apelou ao doutor Samuel, que, demandando contra a Previdência, acertou encostá-la na Caixa, um salário-mínimo limpo, todo quinto dia útil do mês. Alardeavam, o Ana Carra inteiro, que ela sim, tivera sorte, porque, ao invés de encafuar-se em Cataguases, bicho-do-mato atrás de tanque-de-lavar-roupas ou iludida em-dentro de uma tecelagem, correra mundo, tornarase esperta, astuta, ladina, e agora podia desfilar pavã pela cidade [...] (Ruffato, 2011, p. 51).

A passagem, um tanto inverossímil, deve suscitar críticas quanto ao grau de ingenuidade atribuído por Ruffato às personagens que "invejam" o destino de Sandra7. É que há descolamento hierárquico entre personagens pobres e narrador, sendo este último instrumento de certa condescendência da instância autoral empática ${ }^{8}$.

Como os trechos mostrados desvelam, há forte vezo materialista em todas as narrativas de Inferno provisório. Ressaltados os objetos, centrais na composição das cenas, habitualmente o motivo da ascensão social perpassa as narrativas. Nesse universo ficcional de migrantes marginalizados, em que, nos termos de Bourdieu (Cf. 2007 [1979], p. 5456), (quase) não há distância da necessidade, Ruffato encaminha seu texto em direção à concretude referencial, definidora e diferenciadora. Por certo, apenas às classes mais abastadas as coisas devem apresentarse quase que sem importância, sendo a renda cotidiana assegurada em patamares que permitem tal indiferença. Não aqui, em que a violência da carestia é concreta. Portanto, a escrita, levada ao desafio do índice urgente (Schøllhammer, 2007, p. 72), também se circunscreve à certa poética material; que, bem vista, não nega a complexidade subjetiva das

\footnotetext{
${ }^{7}$ Agradeço a Regina Dalcastagnè a indicação desse problema.

${ }^{8}$ Para uma discussão sobre o olhar empático do narrador em Inferno provisório, ver Maria Zilda Ferreira Cury (2007).
} 
personagens, apesar de necessariamente reificar tal dinâmica. Veja-se o caso de "Outra fábula", última narrativa de Inferno provisório. Depara-se, mais uma vez, com o Luís Gustavo de "Era uma vez", história analisada anteriormente. Morador de São Paulo, o agora jornalista relembra o casamento fracassado e a última e malsucedida gravidez da ex-esposa.

Dois anos mais e irrompeu uma nova gravidez. Alertas, redobraram as atenções [...]. Cinco meses privaram com dores e hemorragias, urgentes passagens por pronto-socorros lotados e infectos, braços roxos de veias perfuradas, despenhadas olheiras, brancura de esgotamentos, até uma madrugada a camisola, os lençóis, o edredom, o colchão, o sonho, tudo empapar-se em sangue, extinto abruptamente em anestesia e pinças. Abalados, redemoinharam as discussões [...], um adjetivo suscita rancores incauterizados, um gesto incendeia acusações desvairadas [...]. Culpados, atolavam as dívidas, festas de aniversário em bufês chiques, engenhocas eletrônicas, roupas de grife, carro zeroquilômetro, atrasadas as prestações do plano habitacional, estourados os cartões de crédito, rubras contas bancárias. Onze anos, a solidão a que haviam se condenado.

Imerso entre os milhares de calções e camisetas numeradas, sob um calor de mais de trinta graus, aguardando o sinal para o início da largada da Corrida de São Silvestre, na tarde do último dia de 2002, tudo, tudo isso Luís Augusto buscava esquecer (Ruffato, 2011, p. 106).

O sonho empapa-se em sangue, assim como são rubras as contas bancárias. O alistamento das dores, ao lado do alistamento dos produtos de consumo a crédito, economicamente inviáveis ao casal, dizem da inseparabilidade entre sentimento e poder de compra; entre saúde psíquica e saúde econômica; dinheiro e estabilidade emocional. Os milhares de pessoas ao lado de Luís Augusto são apenas massa (calções e camisetas numeradas); não há pertencimento orgânico à megalópole ${ }^{9}$, bem como urgia mudar-se do interior mineiro.

\footnotetext{
9 "Corpos individuais que transitam pela cidade tornam-se cada vez mais desligados dos lugares em que se movem e das pessoas com quem convivem nesses espaços, desvalorizando-os por meio da locomoção e perdendo a noção de destino compartilhado" (Sennett, 2008 [1994], p. 326). Vê-se que não há razão comum capaz de transcender as crises individuais. À cidadania e à luta política (destino participativo) prevalece o individualismo moderno e o conservadorismo institucional.
} 
Seguindo o pensamento de Certeau (1996 [1990], p. 241), o casal, endividado, seria refém de certa lei, ou o imperativo do consumo, que avança "sobre o corpo, um capital de encarnação, para assim se fazer crer e praticar". Este imperativo, como se sabe, só produz seus praticantes, nos termos de Certeau, ao operar com credibilidade discursiva, fazendo com que a massa, crente, se desloque.

A economia liberal não é menos eficaz que o totalitarismo para efetuar essa articulação da lei pelos corpos. Ela procede apenas segundo outros métodos. Em vez de esmagar os grupos para marcá-los com o ferro único de um só poder, atomiza-os inicialmente e depois multiplica as redes estreitas dos intercâmbios que conformam unidades individuais às regras (ou às "modas") dos contratos socioeconômicos e culturais. Tanto neste como naquele caso, pode-se perguntar por que isso funciona. Que desejo ou que necessidade nos leva assim a fazer de nossos corpos os emblemas de uma lei identificadora? (Certeau, 1996 [1990], p. 241).

Acertadamente, Certeau se lembra das hipóteses que tentam responder a essa indagação mostrando "a força dos laços que os instrumentos estabelecem entre nossas 'naturezas' [...] e as discursividades sociais". Como "escrituras incansáveis" (Certeau, 1996 [1990], p. 240), os corpos sofrem "a instrumentação de um sem-número de leis" e só se tornam socialmente críveis, isto é, encarnados, "graças à sua conformação a esses códigos".

\section{Direito público}

Contraposto à dinâmica simbólica erigida por Luiz Ruffato em Inferno provisório, é preciso atentar para o compromisso com a igualdade formal que tem levado sociedades capitalistas do ocidente a impor regras públicas de seguridade e isonomia no tratamento independentes de sexo, raça, orientação sexual, status social, religião ou outros atributos pessoais, como afirma Iris Young (2000, p. 223) em La justicia y la política de la diferencia. Não é outro o caso brasileiro, em que é inafiançável o crime de racismo. Tais imperativos do direito público levam ao refreamento das expressões discursivas do preconceito, mas são insuficientes no que tange à superação ideal de sua efetividade prática. 
As representações artísticas, portanto, em seu caráter reflexivo minimamente distanciado, se moralmente desassossegadas, surpreendem a convencionalidade de anteparos legais insuficientes ${ }^{10}$. É assim em Inferno provisório, em que o leitor observa os planos muitas vezes inconscientes e automáticos da violência social, os quais, mesmo em casos de cumprimento da lei, fazem com que as relações de opressão e privilégio sigam reproduzindo-se (Young, 2000, p. 225). Por isso, o espaço do corpo na poética ruffatiana pode tanto servir à explicitação dos meios sociais da personagem quanto dizer da impossibilidade de fugir desses meios. Pratos "colorex" (Ruffato, 2008, p. 133), mesas de "fórmica" (Ruffato, 2008, p. 29), roupas "domingueiras" (Ruffato, 2011, p. 16), bolsas de "napa" (Ruffato, 2008, p. 147) etc. juntam-se a pernas "varizentas" (Ruffato, 2011, p. 20), corpos "exaustos" (Ruffato, 2011, p. 28), "rugas e pés-de-galinha e estrias e celulite" (Ruffato, 2011, p. 31) como em um composto único, objetos denotando vidas; vidas inscritas em objetos.

\section{Referências}

BETHENCOURT, Francisco; CURTO, Diogo Ramada (1989). Nota de apresentação. In: BOURDIEU, Pierre. O poder simbólico. Lisboa: Difel; Rio de Janeiro: Bertrand Brasil.

BOURDIEU, Pierre (1989). O poder simbólico. Tradução de Fernando Tomaz. Lisboa: Difel; Rio de Janeiro: Bertrand Brasil.

BOURDIEU, Pierre (2007 [1979]). A distinção: crítica social do julgamento. Tradução de Daniela Kern e Guilherme J. F. Teixeira. São Paulo: Ed. USP; Porto Alegre: Zouk.

CERTEAU, Michel de (1996 [1990]). A invenção do cotidiano. Tradução de Ephraim Ferreira Alves. 2. ed. Petrópolis: Vozes. v. 1 (Artes de fazer).

CURY, Maria Zilda Ferreira (2007). Ética e simpatia: o olhar do narrador em contos de Luiz Ruffato. In: HARRISON, Marguerite Itamar (Org.). Uma cidade

\footnotetext{
10 “Como é possível, por exemplo, que uma sociedade proclame em suas normas formais e em suas instituições públicas que as mulheres são tão competentes como os homens e que, para fins de trabalho profissional, deveriam ser tomadas por seus méritos, quando essa mesma sociedade, de maneira massiva, produz e distribui revistas e filmes comercialmente exitosos que representam o abuso e a degradação da mulher em imagens que se supõe que são sexualmente estimulantes?" (Young, 2000, p. 229, tradução nossa).
} 
em camadas: ensaios sobre o romance Eles eram muitos cavalos, de Luiz Ruffato. Vinhedo: Horizonte.

DALCASTAGNE, Regina (2005). A personagem do romance brasileiro contemporâneo: 1990-2004. Estudos de Literatura Brasileira Contemporânea, n. 26, p. 13-71.

GOFFMAN, Erving (2009 [1959]). A representação do eu na vida cotidiana. Tradução de Maria Célia Santos Raposo. 17. ed. Petrópolis: Vozes.

OLIVEIRA, Marcos Vinícius Ferreira de (2013). Tecido em ruínas: fabricação e corrosão das Cataguases no Inferno provisório, de Luiz Ruffato. São Paulo: Intermeios; Cataguases: Secretaria Municipal de Cultura e Turismo.

RICCIARDI, Giovanni (2007). Pedras para um mosaico. In: HARRISON, Marguerite Itamar (Org.). Uma cidade em camadas: ensaios sobre o romance Eles eram muitos cavalos, de Luiz Ruffato. Vinhedo: Horizonte.

RUFFATO, Luiz (2008). O livro das impossibilidades. Rio de Janeiro: Record. (Inferno provisório, v. 4)

RUFFATO, Luiz (2011). Domingos sem Deus. Rio de Janeiro: Record. (Inferno provisório, v. 5)

SARTRE, Jean-Paul (1997 [1943]). O ser e o nada: ensaio de ontologia fenomenológica. Tradução e notas de Paulo Perdigão. 4. ed. Petrópolis: Vozes.

SCHØLLHAMMER, Karl Erik. Fragmentos do real e o real do fragmento. In: HARRISON, Marguerite Itamar (Org.). Uma cidade em camadas: ensaios sobre o romance Eles eram muitos cavalos, de Luiz Ruffato. Vinhedo: Horizonte, 2007.

SENNETT, Richard (2008 [1994]). Carne e pedra. Tradução de Marcos Aarão Reis. Rio de Janeiro: BestBolso.

YOUNG, Iris Marion (2000). La Justicia y la política de la diferencia. Tradução de Silvina Álvarez. Madrid: Cátedra.

Recebido em agosto de 2014.

Aprovado em dezembro de 2014.

\section{resumo/abstract}

\section{A classe feita corpo: pertencimento e discriminação social em Inferno provisório, de Luiz Ruffato}




\section{Gabriel Estides Delgado}

Em Inferno provisório, Luiz Ruffato confere centralidade à caracterização física de suas personagens migrantes e marginalizadas. A incorporação das estruturas sociais dá-se a ver tanto na hexis corporal, que guarda equivalências com os condicionamentos históricos do portador, quanto no universo de objetos consumidos, que funcionam como índices das condições (e relações) de classe figuradas pelo escritor mineiro. Amplificada a importância dos desejos de ascensão social e poder de consumo das personagens, seus corpos apresentamse como espaços saturados de poder simbólico e linguagem. Para esta análise, foram escolhidas, como narrativas representativas dos demais momentos da poética de Inferno provisório, histórias dos dois últimos livros (volumes IV e V) da série literária - O livro das impossibilidades e Domingos sem Deus.

Palavras-chave: classe, corpo, discriminação, Luiz Ruffato.

\section{Class made flesh: belonging and social discrimination in Luiz Ruffato's Inferno provisório}

\section{Gabriel Estides Delgado}

In Inferno provisório, Luiz Ruffato foregrounds the physical characterization of his migrant and marginalized characters. The incorporation of social structures is visually embodied both in the physical hexis, which maintains similarities with the historical constraints of the carrier, as well as in the universe of consumed objects, which act as indices of the conditions (and relations) of classes portrayed by the Mineiro writer. By amplifying the importance of the characters' desires for social mobility and the power to consume, their bodies appear as saturated spaces of symbolic power and language. For this analysis, stories from the last two books (volumes IV and V) of Ruffato's literary series - O livro das impossibilidades and Domingos sem Deus - were chosen as representative narratives of other poetic moments from Inferno provisório.

Keywords: class, body, discrimination, Luiz Ruffato. 